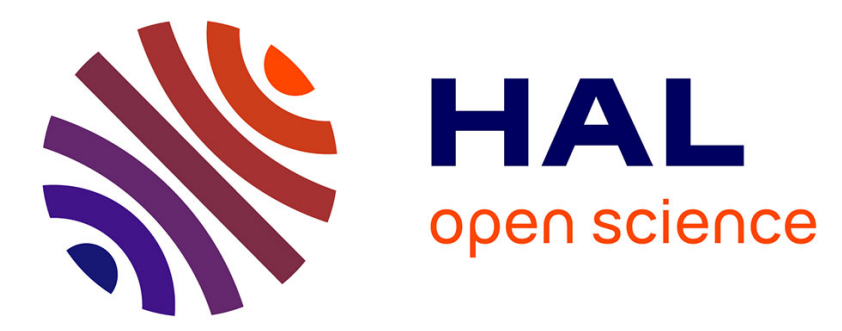

\title{
Synthesis and Structures of Plutonyl Nitrate Complexes: Is Plutonium Heptavalent in PuO3(NO3)2-?
}

Rémi Maurice, Eric Renault, Yu Gong, Philip X. Rutkowski, John K. Gibson

\section{To cite this version:}

Rémi Maurice, Eric Renault, Yu Gong, Philip X. Rutkowski, John K. Gibson. Synthesis and Structures of Plutonyl Nitrate Complexes: Is Plutonium Heptavalent in PuO3(NO3)2-?. Inorganic Chemistry, 2015, 54, pp.2367-2373. 10.1021/ic502969w . in2p3-01121844

\section{HAL Id: in2p3-01121844 \\ https://hal.in2p3.fr/in2p3-01121844}

Submitted on 2 Mar 2015

HAL is a multi-disciplinary open access archive for the deposit and dissemination of scientific research documents, whether they are published or not. The documents may come from teaching and research institutions in France or abroad, or from public or private research centers.
L'archive ouverte pluridisciplinaire HAL, est destinée au dépôt et à la diffusion de documents scientifiques de niveau recherche, publiés ou non, émanant des établissements d'enseignement et de recherche français ou étrangers, des laboratoires publics ou privés. 


\title{
Synthesis and Structuresof Plutonyl Nitrate Complexes: Is Plutonium Heptavalent in $\mathrm{PuO}_{3}\left(\mathrm{NO}_{3}\right)_{2}{ }^{-}$?
}

\author{
RémiMaurice, ${ }^{\mathrm{a},{ }^{*}}$ Eric Renault, ${ }^{\mathrm{b}}$ Yu Gong, ${ }^{\mathrm{c}}$ Philip X. Rutkowski, ${ }^{\mathrm{c}}{ }^{\mathrm{J}}$ ohn K. Gibson ${ }^{\mathrm{c}, *}$ \\ ${ }^{a}$ SUBATECH, UMR CNRS 6457, IN2P3/EMN Nantes/Université de Nantes, 4 rue Alfred \\ Kastler, BP 20722, 44307 Nantes Cedex 3, France \\ ${ }^{\mathrm{b}}$ CEISAM, UMR CNRS 6230, Université de Nantes, 2 rue de la Houssinière, BP 92208, 44322 \\ Nantes Cedex 3, France \\ ${ }^{\mathrm{c} C h e m i c a l ~ S c i e n c e s}$ Division, Lawrence Berkeley National Laboratory, Berkeley, California \\ 94720, USA
}

*Corresponding authors: remi.maurice@ subatech.in2p3.fr; jkgibson@lbl.gov

\begin{abstract}
Gas-phase plutonium nitrate anion complexes were produced by electrospray ionization (ESI) of a plutonium nitrate solution. The ESI mass spectrum included species with all four of the common oxidation states of plutonium: $\mathrm{Pu}(\mathrm{III}), \mathrm{Pu}(\mathrm{IV}), \mathrm{Pu}(\mathrm{V})$ and $\mathrm{Pu}(\mathrm{VI})$.Plutonium nitrate complexes were isolated in a quadrupole ion trap and subjected to collision induced dissociation (CID). CID of complexes of the general formula $\mathrm{PuO}_{\mathrm{x}}\left(\mathrm{NO}_{3}\right)_{\mathrm{y}}{ }^{-}$resulted in the elimination of $\mathrm{NO}_{2}$ to produce $\mathrm{PuO}_{\mathrm{x}+1}\left(\mathrm{NO}_{3}\right)_{\mathrm{y}-1}{ }^{-}$, which in most cases corresponds to an increase in the oxidation state of plutonium. Plutonyl species, $\mathrm{Pu}^{\mathrm{V}} \mathrm{O}_{2}\left(\mathrm{NO}_{3}\right)_{2}{ }^{-}$and $\mathrm{Pu}^{\mathrm{VI}} \mathrm{O}_{2}\left(\mathrm{NO}_{3}\right)_{3}{ }^{-}$, were produced from $\mathrm{Pu}^{\mathrm{III}}\left(\mathrm{NO}_{3}\right)_{4}{ }^{-}$and $\mathrm{Pu}^{\mathrm{IV}}\left(\mathrm{NO}_{3}\right)_{5}{ }^{-}$, respectively, by the elimination of two $\mathrm{NO}_{2}$ molecules. CID of $\mathrm{Pu}^{\mathrm{VI}} \mathrm{O}_{2}\left(\mathrm{NO}_{3}\right)_{3}{ }^{-}$resulted in $\mathrm{NO}_{2}$ elimination to yield $\mathrm{PuO}_{3}\left(\mathrm{NO}_{3}\right)_{2}{ }^{-}$, in which the oxidation state of plutonium could be VII, a known oxidation state in condensed phase but not yet in the gas phase. Density functional theoryconfirmed the nature of $\mathrm{Pu}^{\mathrm{V}} \mathrm{O}_{2}\left(\mathrm{NO}_{3}\right)_{2}{ }^{-}$and $\mathrm{Pu}^{\mathrm{VI}} \mathrm{O}_{2}\left(\mathrm{NO}_{3}\right)_{3}{ }^{-}$as plutonyl(V/VI) cores coordinated by bidentate equatorial nitrate ligands. The computed structure of $\mathrm{PuO}_{3}\left(\mathrm{NO}_{3}\right)_{2}{ }^{-}$is essentially a plutonyl(VI) core, $\mathrm{Pu}^{\mathrm{VI}} \mathrm{O}_{2}{ }^{2+}$, coordinated in the equatorial plane by two nitrate ligands and one radical oxygenatom. The computations indicate that in the ground spin-orbit free state of $\mathrm{PuO}_{3}\left(\mathrm{NO}_{3}\right)_{2}{ }^{-}$, the unpaired electron of the oxygen atom is antiferromagnetically coupled to the spin-triplet state of the plutonyl core. The results indicate that $\mathrm{Pu}$ (VII) is not a readily accessible oxidation state in the gas phase, despite that it is stable in solution and solids, but rather that a $\mathrm{Pu}(\mathrm{VI})$-O.bonding configuration is favored, in which an oxygen radical is involved.
\end{abstract}




\section{Introduction}

Accessing high oxidation states of transuranic actinides, particularly plutonium, has gained much attention. ${ }^{1}$ Hexavalent plutonium is common, primarily in the form of $\mathrm{PuO}_{2}{ }^{2+}$ in solution. A key issue is whether it is feasible to chemically engage the $5 \mathrm{f}^{2}$ electrons of $\mathrm{Pu}(\mathrm{VI})$ to access higher oxidation states. ${ }^{2}$ Krot and Gel'man first reported Pu(VII) in alkaline solution in $1967,{ }^{3}$ a feat shortly thereafter repeated. ${ }^{4}$ Keller and Seiffertsynthesized a solid compound containing $\mathrm{Pu}(\mathrm{VII}){ }^{5}$ More recently, $\mathrm{Pu}(\mathrm{VIII})$ has been reported in solution. ${ }^{6}$ In the gas phase, octavalent $\mathrm{PuO}_{4}$ has been inferred based on thermogravimetric experiments, ${ }^{7}$ as well as from the apparent vaporization of $\mathrm{Pu}$ from alkaline solutions. ${ }^{8}$ However, recent computational studies indicate that $\mathrm{PuO}_{4}$ as a molecule comprising $\mathrm{Pu}(\mathrm{VIII})$ is not stable. ${ }^{9,10}$ Instead, $\mathrm{PuO}_{2} \mathrm{~F}_{4}$ may be a better candidate as a stable species comprising $\mathrm{Pu}(\mathrm{VIII}){ }^{2}$ In the case of $\mathrm{Pu}(\mathrm{VII})$ in the gas phase, it has been predicted that $\mathrm{PuO}_{3} \mathrm{~F}$ and $\mathrm{Pu}_{2} \mathrm{O}_{7}$ should be stable. ${ }^{10}$ The reduction potential in solution for $\mathrm{Pu}^{\mathrm{VII}} \mathrm{O}_{3}{ }^{+} / \mathrm{Pu}^{\mathrm{VI}} \mathrm{O}_{2}{ }^{2+}$ is ca. $+2.3 \mathrm{~V}$, ${ }^{1}$ which is only ca. $0.6 \mathrm{~V}$ higher than the $\mathrm{Ce}(\mathrm{IV} / \mathrm{III})$ reduction potential; $\mathrm{CeO}_{2}$ is a stable molecule ${ }^{11}$ and it might be feasible to oxidize $\mathrm{Pu}(\mathrm{VI})$ to $\mathrm{Pu}(\mathrm{VII})$ in the gas phase. An important caveat in this evaluation is that the reported $\mathrm{Pu}(\mathrm{VII})$ reduction potential is for highly basic conditions such that direct comparison of these values is not necessarily indicative of comparative intrinsic stabilities of the oxidation states.

In accord with the above assessment, the primary goal of the present work was to investigate the stability of $\mathrm{Pu}(\mathrm{VII})$ in gas-phase oxides. The decomposition of gas-phase metal nitrate anions, $\mathrm{M}\left(\mathrm{NO}_{3}\right)_{\mathrm{n}}{ }^{-}$, can result in the elimination of neutral $\mathrm{NO}_{2}$, producing $\mathrm{MO}\left(\mathrm{NO}_{3}\right)_{\mathrm{n}-1}-{ }^{-12-14}$ In cases where higher oxidation states of the metal are accessible than that in the nitrate precursor, oxidation of the metal center can occur during these processes. An example of oxidation by elimination of $\mathrm{NO}_{2}$, and $\mathrm{NO}$, is the conversion of $\mathrm{Mn}^{\mathrm{II}}\left(\mathrm{NO}_{3}\right)_{3}{ }^{-}$to $\mathrm{Mn}^{\mathrm{VII}} \mathrm{O}_{4}{ }^{-}$, in which $\mathrm{Mn}$ is in its highest accessible oxidation state. ${ }^{14}$ Decomposition of plutonium nitrate anions could be a route to oxidation of $\mathrm{Pu}$, possibly to $\mathrm{Pu}(\mathrm{VII})$. It is demonstrated that $\mathrm{PuO}_{\mathrm{x}}\left(\mathrm{NO}_{3}\right)_{\mathrm{y}}{ }^{-}$complexes do indeed lose neutral $\mathrm{NO}_{2}$ molecules upon collision induced dissociation (CID) in a quadrupole ion trap (QIT) resulting in oxidation of $\mathrm{Pu}$, including the formation of plutonyl(V/VI) from $\mathrm{Pu}(\mathrm{III})$ and $\mathrm{Pu}(\mathrm{IV})$ complexes. Based on analogy with the proposed stable $\mathrm{Pu}^{\mathrm{VII}} \mathrm{O}_{3} \mathrm{~F}$ molecule, it may be expected that $\mathrm{PuO}_{3}\left(\mathrm{NO}_{3}\right)_{2}{ }^{-}$ would similarly comprise $\mathrm{Pu}(\mathrm{VII})$. This latter species was produced and its geometric and electronic structures, including the $\mathrm{Pu}$ oxidation state, were evaluated by density functional theory. Moreover, the magnetic coupling constant in $\mathrm{PuO}_{3}\left(\mathrm{NO}_{3}\right)_{2}{ }^{-}$was also assessed.

\section{Experimental Methods}

The experiments reported here were performed using an Agilent 6340 quadrupole ion trap mass spectrometer (QIT/MS) with the electrospray ionization (ESI) source inside a radiological contaminant glove box, as described in detail elsewhere. ${ }^{15}$ All the plutonium nitrate complex anions subjected to CID were produced by ESI of methanol solutions of 200 $\mu \mathrm{MPu}\left(\mathrm{NO}_{3}\right)_{4}$. The plutonium isotope employed was $\mathrm{Pu}-242$, which undergoes alpha-decay with a half-life of $3.8 \times 10^{5} \mathrm{y}$. The $\mathrm{MS}^{\mathrm{n}}$ CID capabilities of the QIT/MS allow isolation of ions with a particular mass-to-charge ratio, $\mathrm{m} / \mathrm{z}$, and subsequent insertion of an ion-molecule reaction time without applying ion excitation. The reactions inside the ion trap occur at a temperature around $300 \mathrm{~K} .{ }^{16}$ In the high-resolution mode, the instrument has a detection range 
of $20-2200 \mathrm{~m} / \mathrm{z}$ with a mass width (FWHM) of $\sim 0.3 \mathrm{~m} / \mathrm{z}$. Mass spectra were recorded in the negative ion accumulation and detection mode. The instrumental parameters were similar to those employed in previous experiments. ${ }^{17}$ High-purity nitrogen gas for nebulization and drying in the ion transfer capillary was supplied from the boil-off of a liquid nitrogen Dewar. As has been discussed elsewhere, ${ }^{18,19}$ the background water and $\mathrm{O}_{2}$ pressure in the ion trap is estimated to be on the order of $10^{-6}$ Torr. The helium buffer gas pressure in the trap is constant at $\sim 10^{-4}$ Torr.

\section{ComputationalApproach}

Quantum mechanical calculations have been performed on the $\mathrm{PuO}_{2}\left(\mathrm{NO}_{3}\right)_{2}{ }^{-}$, $\mathrm{PuO}_{2}\left(\mathrm{NO}_{3}\right)_{3}{ }^{-}$, and $\mathrm{PuO}_{3}\left(\mathrm{NO}_{3}\right)_{2}{ }^{-}$complexes to determine their molecular geometries, and characterize their electronic structures. Various isomers, which may furthermore correspond to different oxidation numbers for the $\mathrm{Pu}$ center, are possible, and therefore molecular quantum mechanics is a useful tool to discriminate between the different possibilities. In order to elucidate the role of the coordination of nitrate ligands on the electronic structures of these systems, the corresponding $\mathrm{PuO}_{2}{ }^{+}, \mathrm{PuO}_{2}{ }^{2+}$, and $\mathrm{PuO}_{3}{ }^{+}$cores have also been studied.

\section{Geometry Optimizations}

The determination of molecular geometries from quantum mechanical calculations requires the use of a given level of theory. In this work, two levels have been employed, a scalar relativistic (SR) oneand another considering spin-orbit (SO) effects. The SR calculations were performed using the Gaussian09 program package, ${ }^{20}$ and are based on density functional theory (DFT). Hybrid exchange-correlation functionalslead to accurate geometries and harmonic frequencies in actinide oxides. ${ }^{21}$ Therefore, in this work, the PBE0 exchange-correlation functional ${ }^{22,23}$ was used, as in previous work of some of uson actinide carbides. ${ }^{24}$ For the Pu atom, the 60-electron small-core pseudo-potential ECP60MWB was considered, ${ }^{25}$ and the remaining electrons described using a $(14 \mathrm{~s} 13 \mathrm{p} 10 \mathrm{~d} 8 \mathrm{f} 6 \mathrm{~g}) / 10 \mathrm{~s} 9 \mathrm{p} 5 \mathrm{~d} 4 \mathrm{f} 3 \mathrm{~g}$ segmented contracted basis set. ${ }^{26}$ For the $\mathrm{O}$ and $\mathrm{N}$ atoms, the (12s6p3d1f)/6s3p3d1f def2TZVPD basis sets ${ }^{27,28}$ were used. Note that diffuse functions were considered due to the anionic nature of the ligands. Various starting geometries were considered, and relaxed with local optimization algorithms. The nature of the encountered stationary points was checked by computing harmonic frequencies, and for all relevant spin configurations, the lowest energy minima were found. The spin nature of the various considered spin configurations was assessed from the $\left\langle S^{2}\right\rangle$ expectation values, computed for the fictitious non-interacting systems of interest. Although no formal relationship exists between Kohn-Sham determinants and true wave functions, these expectation values are used in practice as a measure of the degree of spin state mixings. Note that the numerical grid was defined by using the ultrafine keyword of Gaussian.In order to assess the impact of SO coupling on the molecular geometries, SO-DFT calculations ${ }^{29}$ were performed with the NWChem6.3 suite of programs. ${ }^{30}$ The exchange-correlation functional, the basis sets, and the numerical grid were chosen identical to the ones used in the SR-DFT calculations. The energy adjusted SO pseudopotential of Küchleet al. ${ }^{31}$ was used for these calculations. In NWChem, the collinear approximation is used, which makes the results non-invariant with respect to rotations of the coordinate frame. While the error in total energies can be of the order of $0.1 \mathrm{eV},^{32}$ bond 
distances and atomic charges are not expected to be significantly dependent on the choice of the coordinate frame.

\section{Atomic Charges and Spin Populations}

In order to determine the oxidation number of the $\mathrm{Pu}$ atom in the studied complexes, the SR Mulliken atomic charges and spin populations of the relevant configurations of the $\mathrm{PuO}_{2}\left(\mathrm{NO}_{3}\right)_{2}{ }^{-}, \mathrm{PuO}_{2}\left(\mathrm{NO}_{3}\right)_{3}{ }^{-}$, and $\mathrm{PuO}_{3}\left(\mathrm{NO}_{3}\right)_{2}{ }^{-}$complexes were computed, as well as the $\mathrm{SO}$ Mulliken charges. To assess the role of the coordination of the nitrate ligands on the $\mathrm{PuO}_{2}{ }^{+}$, $\mathrm{PuO}_{2}{ }^{2+}$, and $\mathrm{PuO}_{3}{ }^{+}$cores, these quantities were also determined for these uncoordinated ions. Note that in the $\mathrm{PuO}_{2}{ }^{+}$and $\mathrm{PuO}_{2}{ }^{2+}$ cores, the oxidation numbers of $\mathrm{Pu}$ are unambiguous, $+\mathrm{V}$ and $+\mathrm{VI}$, respectively. Therefore, the comparison of the results obtained in the complexes and with these cores is of crucial importance to determine the oxidation numbers of $\mathrm{Pu}$ in the complexes. Mulliken charges are known to be basis set dependent; therefore, the absolute values of these effective charges are not necessarily meaningful. Moreover, effective charges differ drastically from formal charges, and therefore, effective charge values alone cannot be used to assign oxidation numbers. We have chosen this charge model since it was practically available at all the levels of theory considered in this work, i.e. SR- and SO-DFT. The most important criteria concerning the oxidation number of $\mathrm{Pu}$ is related to atomic spin density. For high oxidation states of $\mathrm{Pu}$, the $\mathrm{Pu}$ spin density is expected to correlate directly with the number of $f$ electrons. Test calculations on the complexes of interest at SR levels showed that our conclusions remain valid if other charge and spin populations models are used, namely CM5 charges $^{33}$ and Hirshfeld spin densities. ${ }^{34}$

\section{Magnetic Coupling in $\mathrm{PuO}_{3}\left(\mathrm{NO}_{3}\right)_{2}^{-}$}

As will be shown, the $\mathrm{PuO}_{3}\left(\mathrm{NO}_{3}\right)_{2}{ }^{-}$complex and the $\mathrm{PuO}_{3}{ }^{+}$core possess two local spins at SR levels, localized on the plutonium atom $i\left(S_{i}=1\right)$ and on one equatorial oxygen radical $j\left(S_{j}=1 / 2\right)$. Therefore, these local spins can result in two coupled spin states, with either $S=1 / 2$ or $S=3 / 2$. At a given geometry, the energy difference between these two coupled spin states can be effectively described using the Heisenberg-Dirac-van Vleck Hamiltonian: ${ }^{35-37}$

$$
\widehat{H}=J \hat{S}_{i} \cdot \hat{S}_{j}
$$

where $J$ is defined as the magnetic coupling constant between the $i$ and $j$ magnetic centers. In this work, the SR calculations are performed within a spin-unrestricted formalism. In this case, solutions for given $M_{S}$ values are obtained, and the spin quantum number $S$ is not imposed. Here, two solutions are computed, corresponding to $M_{S}=3 / 2$ and referred to as the high-spin (HS) solution, and the $M_{S}=1 / 2$ solution, referred to as thespin-broken-symmetry (BS) solution. In the ideal situation of non-interacting spins (such as at the dissociation limit), the HS solution corresponds to a pure quartet spin state, and the BS solution to an ideal mixture of quartet and doublet components, for which the weights correspond to the square of Clebsch-Gordan coefficients (the BS solution would have 1/3 quartet character, and 2/3 doublet character). If one assumes that such situation is encountered, it can easily be shown that the magnetic coupling constant can be in this case extracted within this weak-coupling scheme (WCS) as follows:

$$
J(\mathrm{WCS})=E_{\mathrm{HS}}-E_{\mathrm{BS}}
$$

where $E_{\mathrm{HS}}$ and $E_{\mathrm{BS}}$ correspond to the self-consistent field (SCF) energies of the HS and BS solutions, respectively. If one deviates from this ideal case, the expectation values $\left\langle S^{2}\right\rangle_{\mathrm{HS}}$ and $\left\langle S^{2}\right\rangle_{\mathrm{BS}}$ deviate from their ideal values (here the ideal $\left\langle S^{2}\right\rangle_{\mathrm{HS}}$ value would be $15 / 4$, and the 
$\left\langle S^{2}\right\rangle_{\mathrm{BS}}$ value 7/4), and one may extract the magnetic coupling constant, within the intermediate coupling scheme (ICS) as proposed by Yamaguchi: ${ }^{38,39}$

$$
J(\mathrm{ICS})=2 \frac{E_{\mathrm{HS}}-E_{\mathrm{BS}}}{\left\langle S^{2}\right\rangle_{\mathrm{HS}}-\left\langle S^{2}\right\rangle_{\mathrm{BS}}}
$$

Both schemes are considered in this work, and the values obtained for both are compared.

\section{Results and Discussion}

\section{ESI of Plutonium Nitrate Solution}

ESI of a nominally $\mathrm{Pu}(\mathrm{IV})$ solution resulted in a mass spectrum, displayed in Figure 1, in which it is evident that all four of the common oxidation states of plutonium are present: $\mathrm{Pu}(\mathrm{III}), \mathrm{Pu}(\mathrm{IV}), \mathrm{Pu}(\mathrm{V})$ and $\mathrm{Pu}(\mathrm{VI})$. $\mathrm{ThePu}^{\mathrm{IV}}\left(\mathrm{NO}_{3}\right)_{5}{ }^{-}$and $\mathrm{Pu}^{\mathrm{VI}} \mathrm{O}_{2}\left(\mathrm{NO}_{3}\right)_{3}{ }^{-}$species were dominant in the ESI mass spectrum; assignments of the minor $\mathrm{Pu}^{\mathrm{III}}\left(\mathrm{NO}_{3}\right)_{4}{ }^{-}$and $\mathrm{Pu}^{\mathrm{IV}} \mathrm{O}\left(\mathrm{NO}_{3}\right)_{3}{ }^{-}$peaks were confirmed from their $\mathrm{CID}$ spectra (see Figures $\mathrm{S} 1$ and $\mathrm{S} 2$ ). Unassigned peaks are attributed to impurities in the plutonium nitrate solution, which is typical under these experimental conditions. ${ }^{40}$ Plutonium is known to coexist in its four common oxidation states in solution. ${ }^{1}$ The ESI spectrum illustrates this distinctive phenomenon, but it should be emphasized that ESI mass spectra in general, and this one in particular, do not necessarily directly reflect solution speciation. ${ }^{41}$

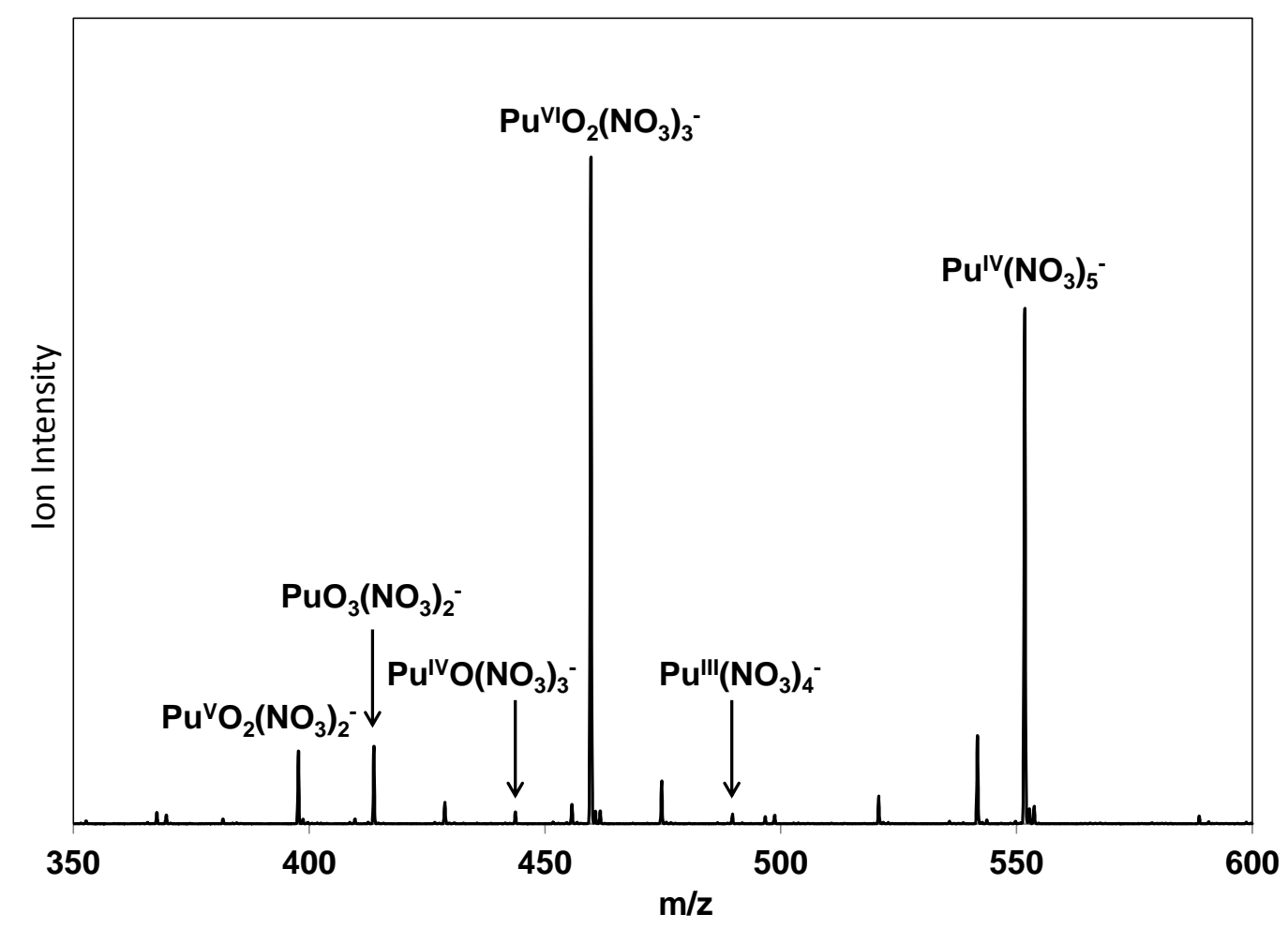

Figure 1.ESI mass spectrum of the plutonium nitrate solution. The assignments of the minor $\mathrm{Pu}\left(\mathrm{NO}_{3}\right)_{4}{ }^{-}$and $\mathrm{PuO}\left(\mathrm{NO}_{3}\right)_{3}{ }^{-}$peaks were confirmed from their CID spectra (Figs. S1 and S2). $\mathrm{CID}$ of $\mathrm{Pu}\left(\mathrm{NO}_{3}\right)_{5}{ }^{-}$and $\mathrm{PuO}_{2}\left(\mathrm{NO}_{3}\right)_{3}{ }^{-}$are discussed below.

For small mononuclear metal complexes, anion ESI mass spectra are generally dominated by ions with charges of -1 or -2 ; only ions with the charge state -1 were observed in the present experiments. In addition to the limitation of observable charge states under 
these experimental conditions, there is the possibility of significant changes in speciation during ESI and ion transport into the ion trap. In the particular case of nitrate ions, facile elimination of $\mathrm{NO}_{2}$ can result in gas-phase oxides that are not present in solution. As discussed below, fragmentation of $\mathrm{Pu}\left(\mathrm{NO}_{3}\right)_{5}{ }^{-}$results in $\mathrm{PuO}_{2}\left(\mathrm{NO}_{3}\right)_{3}{ }^{-}$, which likely accounts for the high abundance of the latter species in the ESI mass spectrum. Despite caveats about quantitative speciation evaluations by ESI, ${ }^{41}$ anion complexes present in solution are generally apparent in ESI mass spectra. Thus, the appearance of substantial $\mathrm{Pu}\left(\mathrm{NO}_{3}\right)_{5}{ }^{-}$in the ESI mass spectrum suggests that this $\mathrm{Pu}(\mathrm{IV})$ species is present in solution. In contrast, from solution speciation studies it has been suggested that $\mathrm{Pu}\left(\mathrm{NO}_{3}\right)_{5}{ }^{-}$is not significant at any nitrate concentration. ${ }^{42}$ Largely based on that work, thermodynamic modeling of plutonium nitrate speciation includes neutral $\mathrm{Pu}\left(\mathrm{NO}_{3}\right)_{4}$ and dianionic $\mathrm{Pu}\left(\mathrm{NO}_{3}\right)_{6}{ }^{2-}$, but excludes $\mathrm{Pu}\left(\mathrm{NO}_{3}\right)_{5}{ }^{-43}$ There seems to be no obvious rationale as to why $\mathrm{Pu}\left(\mathrm{NO}_{3}\right)_{5}{ }^{-}$should not be a stable solution species - the present results show that it is a stable gas phase species that results from ESI of plutonium nitrate solutions, suggesting that its existence in solution is probable. It must be emphasized that the importance of $\mathrm{Pu}\left(\mathrm{NO}_{3}\right)_{5}{ }^{-}$at various nitrate concentrations (and other solution conditions) remains uncertain, and furthermore that the solvent in this work was primarily methanol rather than water. However, based on the ESI results in this work, $\mathrm{Pu}\left(\mathrm{NO}_{3}\right)_{5}{ }^{-}$should be considered when modeling speciation in plutonium nitrate solutions.

\section{Gas-Phase Synthesis of $\mathrm{PuO}_{x}\left(\mathrm{NO}_{3}\right)_{y}{ }^{-}$}

The CID spectra exhibited a variety of processes corresponding to oxidation of $\mathrm{Pu}$ by loss of $\mathrm{NO}_{2}$, such as reaction 1, which are the focus of this work.Reduction processes such as by $\mathrm{NO}_{3}$ ligand loss, reaction 2 , were also observed but are not pertinent to the quest for higher oxidation states of $\mathrm{Pu}$.

$$
\begin{aligned}
& \mathrm{Pu}^{\mathrm{IV}} \mathrm{O}\left(\mathrm{NO}_{3}\right)_{3}{ }^{-} \rightarrow \mathrm{Pu}^{\mathrm{V}} \mathrm{O}_{2}\left(\mathrm{NO}_{3}\right)_{2}{ }^{-}+\mathrm{NO}_{2} \\
& \mathrm{Pu}^{\mathrm{VI}} \mathrm{O}_{2}\left(\mathrm{NO}_{3}\right)_{3}{ }^{-} \rightarrow \mathrm{Pu}^{\mathrm{V}} \mathrm{O}_{2}\left(\mathrm{NO}_{3}\right)_{2}{ }^{-}+\mathrm{NO}_{3}
\end{aligned}
$$

Among the observed redox processes in the CID spectra (Figs. 2,3,S1, S2) were $\mathrm{Pu}(\mathrm{III} \rightarrow \mathrm{IV}$ ), $\mathrm{Pu}(\mathrm{III} \rightarrow \mathrm{V}), \mathrm{Pu}(\mathrm{III} \rightarrow \mathrm{VI}), \mathrm{Pu}(\mathrm{IV} \rightarrow \mathrm{V}), \mathrm{Pu}(\mathrm{IV} \rightarrow \mathrm{VI})$ and $\mathrm{Pu}(\mathrm{VI} \rightarrow \mathrm{V})$. Theprimary motivations for this work werereactions that convert a $\mathrm{Pu}(\mathrm{III})$ or $\mathrm{Pu}(\mathrm{IV})$ nitrate anion into plutonyl, and on the formation of a plutonium nitrate complex with an abnormally high number of oxygen atoms bonded to plutonium. The observed reactions that produce these species are presented, followed by a discussion of theirgeometries and electronic structures, including the $\mathrm{Pu}$ oxidation states. The "reactions" discussed here are induced by CID of an anionic plutonium nitrate complex that has been isolated in the ion trap and is subsequently fragmented after resonant excitation and multiple energetic collisions with helium atoms in the trap prior to acquiring the product mass spectrum. These "reactions" are thus unimolecular decompositions of the specified complex anion, not reactions with any reagent gas in the ion trap. It should be remarked that the instrumental low mass limit for resonant ejection after CID precludes the identification of low $\mathrm{m} / \mathrm{z}$ anion products such as $\mathrm{NO}_{2}{ }^{-}$.

The two reactions that convert plutonium nitrate complexes to plutonyl(V) and plutonyl(VI) complexes are given by reactions 3 and 4, with the corresponding CID spectra shown in Figures $\mathrm{S} 1$ and 2, respectively.

$$
\begin{aligned}
& \mathrm{Pu}^{\mathrm{III}}\left(\mathrm{NO}_{3}\right)_{4}{ }^{-} \rightarrow \mathrm{Pu}^{\mathrm{V}} \mathrm{O}_{2}\left(\mathrm{NO}_{3}\right)_{2}{ }^{-}+2\left(\mathrm{NO}_{2}\right) \\
& \mathrm{Pu}^{\mathrm{IV}}\left(\mathrm{NO}_{3}\right)_{5}{ }^{-} \rightarrow \mathrm{Pu}^{\mathrm{VI}} \mathrm{O}_{2}\left(\mathrm{NO}_{3}\right)_{3}{ }^{-}+2\left(\mathrm{NO}_{2}\right)
\end{aligned}
$$




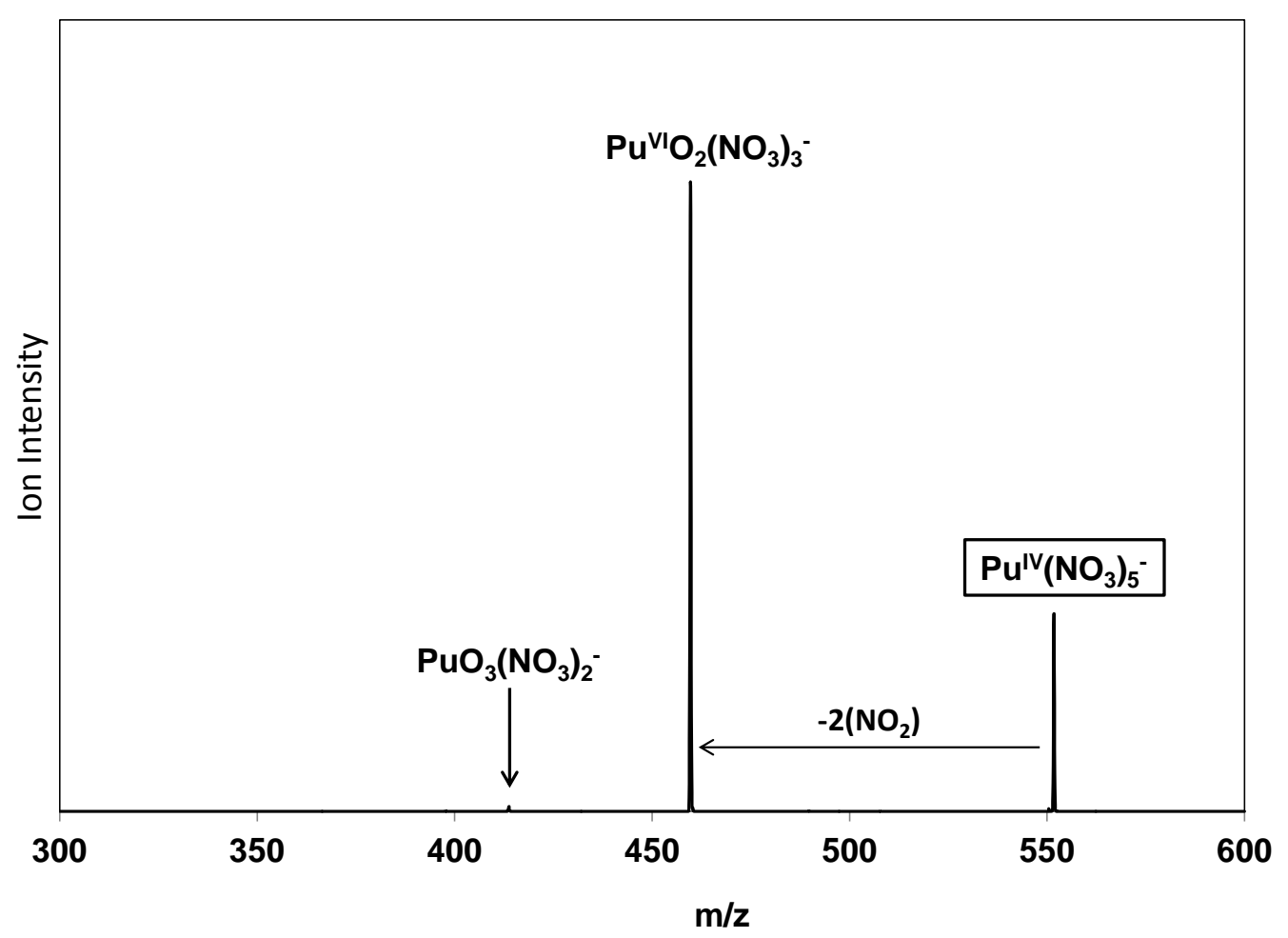

Figure 2.CID mass spectrum of $\mathrm{Pu}\left(\mathrm{NO}_{3}\right)_{5}{ }^{-}$. The dominant channel is to produce plutonyl(VI) nitrate. A very small amount of $\mathrm{PuO}_{3}\left(\mathrm{NO}_{3}\right)_{2}{ }^{-}$is also produced, presumably by loss of a third neutral $\mathrm{NO}_{2}$ molecule from the dominant intermediate.

Rather than $2\left(\mathrm{NO}_{2}\right)$, the product in reactions 3 and 4 could alternatively be $\mathrm{N}_{2} \mathrm{O}_{4}$, the formation of which is slightly less endothermic (by ca. $50 \mathrm{~kJ} / \mathrm{mol}$ ) but essentially degenerate in energy when $\Delta \mathrm{G}$ at $300 \mathrm{~K}$ is considered. ${ }^{44}$ There is little doubt as to the general nature and oxidation states of the plutonyl(V/VI) nitrate products in equations 2 and 3 , but their geometries and electronic structures were evaluated indetail by the computations discussed below. The ability to produce plutonyl(V) and plutonyl(VI) complexes by CID of plutonium(III) and plutonium(IV) nitrates is enabled by the low enthalpy and favorable entropy for reaction 5, and by the low reduction potentials for $\mathrm{Pu}(\mathrm{V} / \mathrm{III})$ and $\mathrm{Pu}(\mathrm{VI} / \mathrm{IV})$, which are both approximately $1 \mathrm{~V}$.

$$
\mathrm{NO}_{3} \rightarrow \mathrm{NO}_{2}+\mathrm{O} \quad(5) \quad \Delta \mathrm{H}=211 \mathrm{~kJ} / \mathrm{mol}^{45}
$$

The direct synthesis of plutonylcomplexes from decomposition and oxidation of plutonium nitrates is significant. A second central goal of this work was to explore the possibility of further oxidizing $\mathrm{Pu}(\mathrm{VI})$ to $\mathrm{Pu}(\mathrm{VII})$ by additional loss of $\mathrm{NO}_{2}$. As is seen in Figure 3, CID reaction 6 proceeds efficiently.

$$
\mathrm{PuO}_{2}\left(\mathrm{NO}_{3}\right)_{3}{ }^{-} \rightarrow \mathrm{PuO}_{3}\left(\mathrm{NO}_{3}\right)_{2}{ }^{-}+\mathrm{NO}_{2}
$$




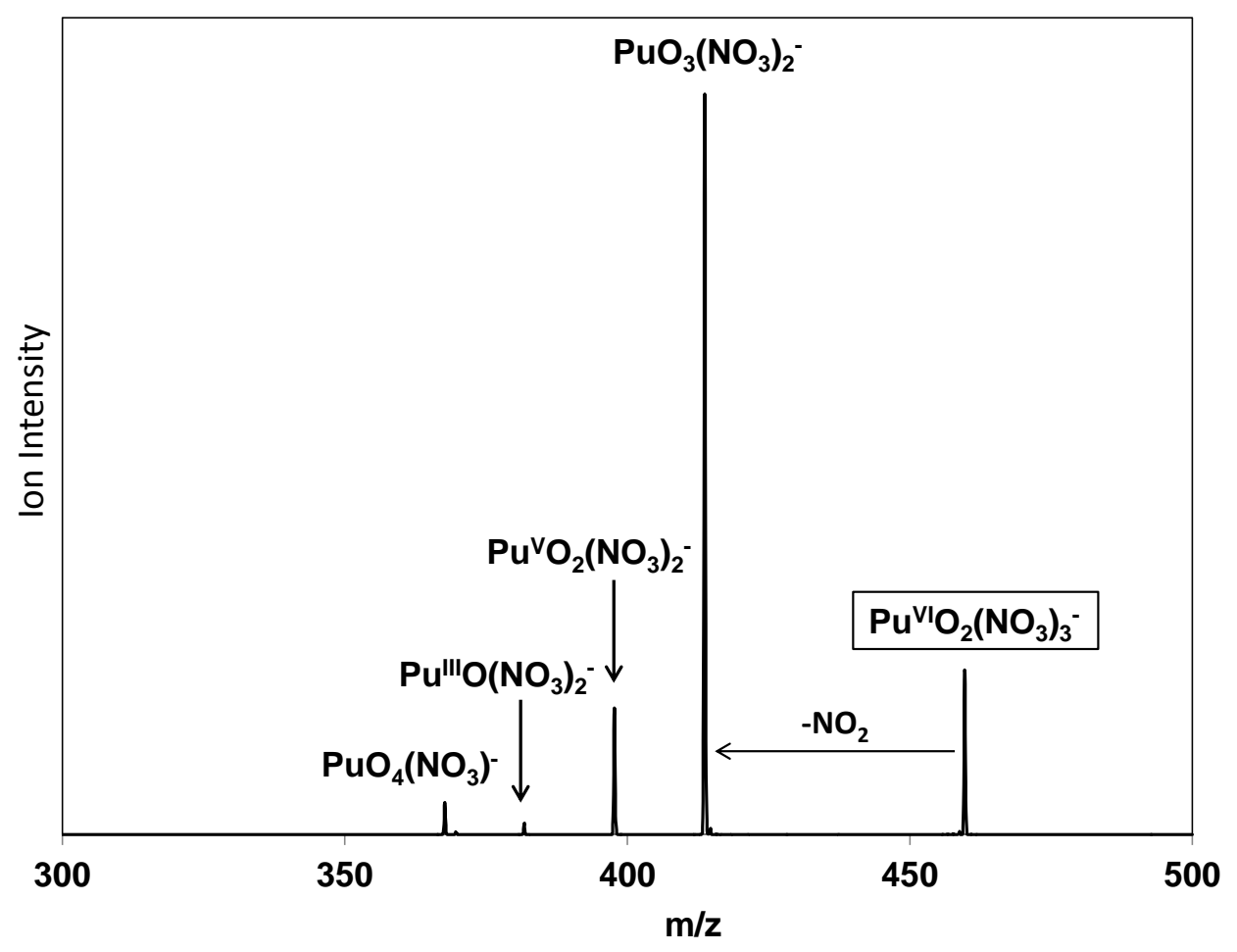

Figure 3. CID mass spectrum of $\mathrm{PuO}_{2}\left(\mathrm{NO}_{3}\right)_{3}{ }^{-}$. The dominant channel is to produce $\mathrm{PuO}_{3}\left(\mathrm{NO}_{3}\right)^{-}$. Another significant channel is production of $\mathrm{PuO}_{2}\left(\mathrm{NO}_{3}\right)_{2}$.

Given that the $\mathrm{Pu}(\mathrm{VII} / \mathrm{VI})$ reduction potential is modest, $0.85 \mathrm{~V}$ in basic solution, ${ }^{1}$ it is conceivable that the product of reaction 6 is plutonium trioxide coordinated by two nitrate anions, with an oxidation state of $\mathrm{Pu}(\mathrm{VII})$. It should be emphasized that there is not necessarily a direct correlation between reduction potentials in solution, particularly basic solution, and the propensity for redox processes to occur in gas phase complexes. Solution reduction potentials cannot be employed to predict whether a gas-phase oxidation process will proceed, but they can be employed as a qualitative guide for the general feasibility of oxidation. In particular, the oxidation behavior of $\mathrm{Pu}$ in basic solution does not necessarily indicate that the $\mathrm{Pu}$ (VII) oxidation state should be similarly accessible in the gas phase, but it does suggest this as a reasonable target. An alternative structure is plutonyl(V) nitrate coordinated by an oxygen radical to yield an oxidation state of $\mathrm{Pu}(\mathrm{VI})$. This latter scenario is seen in such species as $\mathrm{CaO}\left(\mathrm{NO}_{3}\right)_{2}{ }^{-}$, where the $\mathrm{Ca}$ (III) oxidation state is essentially inaccessible. ${ }^{14}$ Also apparent in Figure 3 is a small peak that corresponds to $\mathrm{PuO}_{4}\left(\mathrm{NO}_{3}\right)^{-}$, which could conceivably be $\mathrm{Pu}(\mathrm{VIII})$ tetraoxide coordinated by a nitrate. However, the octavalent oxidation state is less viable than $\mathrm{Pu}(\mathrm{VII})$ and it has furthermore been convincingly demonstrated by theory that the oxidation state in the neutral $\mathrm{PuO}_{4}$ core is not even $\mathrm{Pu}(\mathrm{VI})$, but rather remarkably only $\mathrm{Pu}(\mathrm{V}):\left(\mathrm{PuO}_{2}{ }^{+}\right)\left(\mathrm{O}_{2}\right)^{-}{ }^{-9}$. The computed molecular geometries and electronic structures of $\mathrm{Pu}^{\mathrm{V}} \mathrm{O}_{2}\left(\mathrm{NO}_{3}\right)_{2}{ }^{-}, \mathrm{Pu}^{\mathrm{VI}} \mathrm{O}_{2}\left(\mathrm{NO}_{3}\right)_{3}{ }^{-}$and $\mathrm{PuO}_{3}\left(\mathrm{NO}_{3}\right)^{-}$are presented below. As the nomenclature of the first two of these species suggests, they could confidently be assigned as plutonyl(V) and plutonyl(VI) nitrates, which is confirmed and elaborated by the theory results below. The nature of $\mathrm{PuO}_{3}\left(\mathrm{NO}_{3}\right)_{2}{ }^{-}$is not similarlyapparent and computations were needed to characterize this exotic species.

\section{Molecular Geometries}


The optimized geometries shown in Figure 4 for the $\mathrm{PuO}_{2}\left(\mathrm{NO}_{3}\right)_{2}{ }^{-}$(left), $\mathrm{PuO}_{2}\left(\mathrm{NO}_{3}\right)_{3}{ }^{-}$ (middle) and $\mathrm{PuO}_{3}\left(\mathrm{NO}_{3}\right)_{2}{ }^{-}$(right) complexes correspond to $M_{\mathrm{S}}$ values of $3 / 2$, 1 , and $3 / 2$ respectively. Note that the ground spin configuration of the $\mathrm{PuO}_{3}\left(\mathrm{NO}_{3}\right)_{2}{ }^{-}$complex is the same the one of the barePuO ${ }_{3}{ }^{+}$ions, i.e. $M_{\mathrm{S}}=1 / 2$.It is known from multiconfigurational wave function based calculations that the ground spin state of theplutonyl $\mathrm{PuO}_{2}{ }^{+}$core is a quartet, ${ }^{46}$ and the one of the plutonyl $\mathrm{PuO}_{2}{ }^{2+}$ corea triplet. ${ }^{47,48}$ Thus, the present DFT calculations are in agreement with these results. Since for the $\mathrm{PuO}_{3}\left(\mathrm{NO}_{3}\right)_{2}{ }^{-}$complex and the $\mathrm{PuO}_{3}{ }^{+}$core the ground $M_{\mathrm{S}}=1 / 2$ configurations do not correspond to pure spin states $\left(\left\langle S^{2}\right\rangle=1.74\right.$ and $\left\langle S^{2}\right\rangle=1.72$, respectively), but rather to a BS solution (see theElectronic Structures section), the higher-energy HS geometry, which is similar to the ground BS geometrywhile more physically grounded,is also reported, and used for the calculation of the magnetic coupling constants as discussed below. The HS configuration is only $123 \mathrm{meV}(12$ $\mathrm{kJ} / \mathrm{mol}$ ) higher in energy than the BS configuration at the HS geometry (see the Magnetic Coupling section).The optimal geometries of the $\mathrm{PuO}_{2}\left(\mathrm{NO}_{3}\right)_{2}{ }^{-}$and $\mathrm{PuO}_{2}\left(\mathrm{NO}_{3}\right)_{3}{ }^{-}$complexes, as well as the geometry of the HS solution for $\mathrm{PuO}_{3}\left(\mathrm{NO}_{3}\right)_{2}{ }^{-}$are shown in Figure 4, and the most relevant geometrical parameters reported in Table 1 (see Table $\mathrm{S} 1$ for the $\mathrm{PuO}_{2}{ }^{+}$, $\mathrm{PuO}_{2}{ }^{2+}$, and $\mathrm{PuO}_{3}{ }^{+}$cores). In all the considered complexes, a linear O-Pu-O arrangement is observed, while the other fragments (nitrates or oxygen) are located in the equatorial plane, with much longerPu-O distances than for those oxygen atoms in the axial orientation. The structure of the $\mathrm{PuO}_{3}{ }^{+}$core is unusual in that it consists of a linear plutonyl moiety with the third oxygen atomin the equatorial plane. Note that a geometry of the $\mathrm{PuO}_{2}\left(\mathrm{NO}_{3}\right)_{3}{ }^{-}$complex has been recently computed by Odoh and Schreckenbach ${ }^{49}$ and that the geometry obtained in this work is in very good agreement with their reported structure.For all three of the complexes studied here the axial Pu-O distances are close to $1.7 \AA$, which is typical for plutonyl units.Coordination by equatorial nitrate ligands slightly destabilizes the $\mathrm{Pu}-\mathrm{O}$ bonds (see the distances reported in Tables 1 and S1). Although all the converged geometries strictly belong to the $\mathrm{C}_{1}$ symmetry point group, the $\mathrm{PuO}_{2}\left(\mathrm{NO}_{3}\right)_{2}{ }^{-}$geometry can be considered as $\mathrm{D}_{2} \mathrm{~h}$ symmetry, while the $\mathrm{PuO}_{2}\left(\mathrm{NO}_{3}\right)_{3}{ }^{-}$and $\mathrm{PuO}_{3}\left(\mathrm{NO}_{3}\right)_{2}{ }^{-}$complexes are close to $\mathrm{C}_{3 \mathrm{~h}}$ symmetry and $\mathrm{C}_{2 \mathrm{v}}$ symmetry, respectively.For all the studied systems, the SO-DFT geometries (see Table S2) are in good agreement with the SR-DFT ones (see Tables 1 and S1), with only a slight shortening of the $\mathrm{Pu}-\mathrm{O}$ equatorial bond in $\mathrm{PuO}_{3}\left(\mathrm{NO}_{3}\right)_{2}{ }^{-}$. However, this change is not expected to modify the oxidation number of the plutonium center (see the following section), such that only the SR results are reported in the main text.
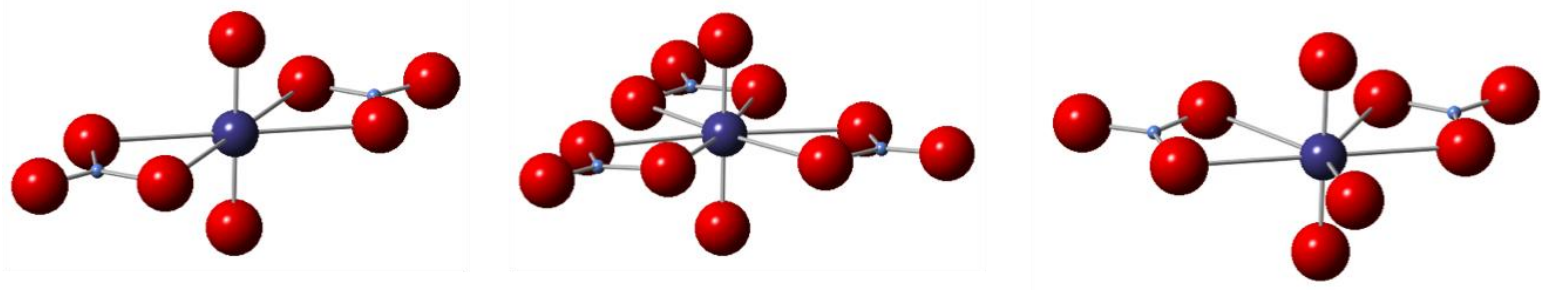

Figure 4. Ball and stick representations of the $\mathrm{PuO}_{2}\left(\mathrm{NO}_{3}\right)_{2}{ }^{-}$(left), $\mathrm{PuO}_{2}\left(\mathrm{NO}_{3}\right)_{3}{ }^{-}$(middle), and $\mathrm{PuO}_{3}\left(\mathrm{NO}_{3}\right)_{2}{ }^{-}$(right) complexes. For the $\mathrm{PuO}_{3}\left(\mathrm{NO}_{3}\right)_{2}{ }^{-}$complex, the high-spin (HS) configuration geometry is shown, the ground-state BS one being practically the same. Color code : $\mathrm{Pu}$ (violet), $\mathrm{O}$ (red), and $\mathrm{N}($ blue $)$. 
Table 1. Scalar-relativistic geometrical parameters of the $\mathrm{PuO}_{2}\left(\mathrm{NO}_{3}\right)_{2}{ }^{-}, \mathrm{PuO}_{2}\left(\mathrm{NO}_{3}\right)_{3}{ }^{-}$, and $\mathrm{PuO}_{3}\left(\mathrm{NO}_{3}\right)_{2}{ }^{-}$complexes.

\begin{tabular}{cccc}
\hline Complex & $\boldsymbol{d}\left(\mathbf{P u}-\mathbf{O}_{\mathbf{1}, 2}\right)^{\mathrm{a}}(\AA)$ & $\boldsymbol{\alpha}\left(\mathbf{O}_{\mathbf{1}}-\mathbf{P u}-\mathbf{O}_{2}\right)^{\mathrm{a}}\left(^{\circ}\right)$ & $\boldsymbol{d}\left(\mathbf{P u}-\mathbf{O}_{\mathbf{3}}\right)^{\mathrm{b}}(\AA)$ \\
\hline $\mathrm{PuO}_{2}\left(\mathrm{NO}_{3}\right)^{2-}$ & 1.75 & 180.0 & N/A \\
$\mathrm{PuO}_{2}\left(\mathrm{NO}_{3}\right)_{3}{ }^{-}$ & 1.71 & 179.8 & N/A \\
$\mathrm{PuO}_{3}\left(\mathrm{NO}_{3}\right)_{2}{ }^{-}(\mathrm{HS})$ & 1.72 & 178.7 & 2.12 \\
$\mathrm{PuO}_{3}\left(\mathrm{NO}_{3}\right)_{2}{ }^{-}(\mathrm{BS})$ & 1.72 & 179.9 & 2.08 \\
\hline
\end{tabular}

${ }^{\mathrm{a}} \mathrm{O}_{1}$ and $\mathrm{O}_{2}$ correspond to the oxygen atoms of the plutonyl units.

${ }^{\mathrm{b}} \mathrm{O}_{3}$ corresponds to the oxygen atom that does not belong to a plutonylor nitrate unit.

\section{Electronic Structures}

In order to further describe the electronic structure of these systems, Mulliken atomic charges and spin populations were computed (see Tables 2 and S7). In the $\mathrm{PuO}_{2}\left(\mathrm{NO}_{3}\right)_{2}{ }^{-}$ complex, as in the $\mathrm{PuO}_{2}{ }^{+}$core, the $\mathrm{Pu}$ atom possess three unpaired electrons, which indicates a $\mathrm{Pu}(\mathrm{V})$ oxidation state. Note that in the $\mathrm{PuO}_{2}{ }^{+}$core, these unpaired electrons are located on non-bonding $\delta_{\mathrm{u}}$ and $\phi_{\mathrm{u}}$ forbitals of the $\mathrm{Pu}$ atom. ${ }^{46}$ In the $\mathrm{PuO}_{2}\left(\mathrm{NO}_{3}\right)_{3}{ }^{-}$complex, as well as in the $\mathrm{PuO}_{2}{ }^{2+}$ core, two unpaired electrons are associated with the $\mathrm{Pu}$ atom, which corresponds to a $\mathrm{Pu}(\mathrm{VI})$ oxidation state. In the $\mathrm{PuO}_{2}{ }^{2+}$ core, due to the use of a single-determinental picture, SR-DFT leads to a $\delta_{\mathrm{u}}{ }^{2}$ electronic structure instead of the $\delta_{\mathrm{u}}{ }^{1} \phi_{\mathrm{u}}{ }^{1}$ one. ${ }^{47,48,50,51}$ The $\delta_{\mathrm{u}}$ and $\phi_{\mathrm{u}}$ levels being non-bonding in this core, this does not affect much computed geometries, atomic charges and atomic spin densities, which are the important quantities reported in this work. However, in order to simplify the discussion and avoid confusion, the Kohn-Sham orbitals bearing the unpaired electrons are not plotted.In the $\mathrm{PuO}_{3}\left(\mathrm{NO}_{3}\right)_{2}{ }^{-}$complex (for both the HS and BS geometries), two unpaired electrons are associated with the $\mathrm{Pu}$ atom, while the effective $\mathrm{Pu}$ charge is very close to thatin the $\mathrm{PuO}_{2}\left(\mathrm{NO}_{3}\right)_{3}{ }^{-}$complex. Moreover, the "lone" oxygen atom, $\mathbf{O}_{\mathbf{3}}$, has one unpaired electron, either coupled ferromagnetically to the plutonyl triplet (HS solution) or antiferromagnetically (BS solution). The same behavior is obtained for the $\mathrm{PuO}_{3}{ }^{+}$core. Therefore, it is concluded that the $\mathrm{Pu}$ atom is not further oxidized in the $\mathrm{PuO}_{3}\left(\mathrm{NO}_{3}\right)_{2}{ }^{-}$complex compared with $\mathrm{PuO}_{2}\left(\mathrm{NO}_{3}\right)_{3}{ }^{-}$, i.e. the plutonium oxidation state is $\mathrm{Pu}(\mathrm{VI})$, not $\mathrm{Pu}(\mathrm{VII})$, in the $\mathrm{PuO}_{3}\left(\mathrm{NO}_{3}\right)_{2}{ }^{-}$complex. From these results, one can easily understand that the SO coupling cannot significantlyaffectthe molecular geometries of these plutony systems, since it essentially mixes the ground SO free configuration with configurations that belong tothe same electronic configuration, or with configurations that only differ by the occupation of the essentially non-bonding $f$ orbitals of the Pu center. For instance, in the $\mathrm{PuO}_{2}\left(\mathrm{NO}_{3}\right)_{2}{ }^{-}$case, as in the $\mathrm{PuO}_{2}{ }^{+}$core, the $\phi_{\mathrm{u}}{ }^{2} \delta_{\mathrm{u}}{ }^{1}$ and $\phi_{\mathrm{u}}{ }^{1} \delta_{\mathrm{u}}{ }^{2}$ configurations are coupled and mixed in the ground SO state due to SO coupling (with quartet and doublet spin components), while in $\mathrm{PuO}_{2}\left(\mathrm{NO}_{3}\right)_{3}{ }^{-}$, as inPuO${ }_{2}{ }^{2+}$, the ground $\mathrm{SO}$ state, obtained from multiconfigurational wave function calculations, is found to beessentially constituted of the $\phi_{\mathrm{u}}{ }^{1} \delta_{\mathrm{u}}{ }^{1}$ configuration ${ }^{46}$ (with triplet and singlet spin components). In the $\mathrm{PuO}_{3}\left(\mathrm{NO}_{3}\right)_{2}{ }^{-}$complex, 
the lowest energy doublet and quartet components are expected be mixed by SO coupling. These components correspond to a similar electronic structure, with two unpaired electrons on the $\mathrm{Pu}$ center, and one unpaired electron on the oxygen radical. For similar reasons, the atomic charges are harlyaffected by SO coupling (see Tables 2, S1, andS8), and therefore, the qualitative conclusions concerning the oxidation states of the $\mathrm{Pu}$ centers in these nitrate complexes are independent of the introduction of SO coupling. However, one should note that the SO coupling breaks the spin symmetry, and that its proper inclusion would result in a quartet/doublet mixture in the ground $\mathrm{SO}$ state of the $\mathrm{PuO}_{2}\left(\mathrm{NO}_{3}\right)_{2}{ }^{-}$and $\mathrm{PuO}_{3}\left(\mathrm{NO}_{3}\right)_{2}{ }^{-}$systems (and also in the corresponding $\mathrm{PuO}_{2}{ }^{+}$and $\mathrm{PuO}_{3}{ }^{+}$cores), as well as in a triplet/singlet mixture in the $\mathrm{PuO}_{2}\left(\mathrm{NO}_{3}\right)_{3}{ }^{-}$complex (and in the $\mathrm{PuO}_{2}{ }^{2+}$ core). The numerical determination of these mixtures can be obtained from two-step SO approaches within a multiconfigurational framework, as done by La Macchiaet al. in the $\mathrm{PuO}_{2}{ }^{+}$and $\mathrm{PuO}_{2}{ }^{2+}$ cores. ${ }^{46}$ However, this task is beyond the scope of the present work, which focuses on the molecular geometries and oxidation states of the synthesizedplutonyl nitrate complexes.

Table 2.Scalar-relativistic Mulliken atomic charges $(q)$ and atomic spin populations $(\mu)$ of the $\mathrm{PuO}_{2}\left(\mathrm{NO}_{3}\right)_{2}{ }^{-}, \mathrm{PuO}_{2}\left(\mathrm{NO}_{3}\right)_{3}{ }^{-}$, and $\mathrm{PuO}_{3}\left(\mathrm{NO}_{3}\right)_{2}{ }^{-}$complexes.

\begin{tabular}{ccccccc}
\hline Complex & \multicolumn{2}{c}{$\mathbf{P u}$} & \multicolumn{2}{c}{$\mathbf{O}_{1,2}{ }^{\mathrm{a}}$} & \multicolumn{2}{c}{$\mathbf{O}_{3}{ }^{\mathrm{b}}$} \\
& $\boldsymbol{q}(\mathbf{e})$ & $\boldsymbol{\mu}\left(\mathbf{e}^{-}\right)$ & $\boldsymbol{q}(\mathbf{e})$ & $\boldsymbol{\mu}\left(\mathbf{e}^{-}\right)$ & $\boldsymbol{q}(\mathbf{e})$ & $\boldsymbol{\mu}\left(\mathbf{e}^{-}\right)$ \\
\hline $\mathrm{PuO}_{2}\left(\mathrm{NO}_{3}\right)_{2}{ }^{-}$ & 1.78 & 3.41 & -0.67 & -0.18 & N/A & N/A \\
$\mathrm{PuO}_{2}\left(\mathrm{NO}_{3}\right)_{3}{ }^{-}$ & 2.37 & 2.38 & -0.66 & -0.15 & N/A & N/A \\
$\mathrm{PuO}_{3}\left(\mathrm{NO}_{3}\right)_{2}{ }^{-}(\mathrm{HS})$ & 2.34 & 2.29 & -0.64 & -0.12 & -0.61 & 0.98 \\
$\mathrm{PuO}_{3}\left(\mathrm{NO}_{3}\right)_{2}^{-}(\mathrm{BS})$ & 2.31 & 2.45 & -0.65 & -0.18 & -0.57 & -1.05 \\
\hline
\end{tabular}

${ }^{\mathrm{a}} \mathrm{O}_{1}$ and $\mathrm{O}_{2}$ correspond to the oxygen atoms of the plutonyl units. Computed values for $\mathrm{O}_{1}$ and $\mathrm{O}_{2}$ differ by less than 0.01 in all the reported cases.

${ }^{\mathrm{b}} \mathrm{O}_{3}$ corresponds to the oxygen atom that does not belong to any plutonyl or nitrate unit.

\section{Magnetic Coupling in $\mathrm{PuO}_{3}\left(\mathrm{NO}_{3}\right)_{2}^{-}$}

To extend our SR-DFT study, the magnetic coupling constant in the $\mathrm{PuO}_{3}\left(\mathrm{NO}_{3}\right)_{2}{ }^{-}$ complex was computed for the HS geometry. From the results shown in Table 3, we obtain a $J$ value of 123 meVwith both the WCS and the ICS. These values are practically identical, which is not surprising given that the computed values of $\left\langle S^{2}\right\rangle_{\mathrm{HS}}$ and $\left\langle S^{2}\right\rangle_{\text {BS }}$ arevery close to the ideal ones of the WCS (3.75 and 1.75, respectively). Therefore, it is concluded that an oxygen radical is present in the $\mathrm{PuO}_{3}\left(\mathrm{NO}_{3}\right)_{2}{ }^{-}$complex, and that its unpaired electron is antiferromagnetically coupled to plutonium, with a large coupling constant. Therefore, the ground SO free state is a spin doublet, and the ground SO state is predicted to have a dominant doublet character. Indeed, due to the absence of an inversion center, the doublet and quartet components mix under the effect of SO coupling, which is often referred to as 
antisymmetric exchange or Dzyaloshinskii-Moriya interaction. ${ }^{52-54}$ By comparing Tables 2 and S9, one can see that the magnetic coupling constant is strongly affected by the coordination of equatorial nitrate ligands. This parameter is known to be strongly dependent on the geometry, and it should be noted that the smaller coupling value in the $\mathrm{PuO}_{3}\left(\mathrm{NO}_{3}\right)_{2}{ }^{-}$ complex is associated with a larger $\mathrm{Pu}-\mathrm{O}_{3}$ distance than in the $\mathrm{PuO}_{3}{ }^{+}$core.

Table 3.Energy difference between the high-spin (HS) andspin-broken-symmetry (BS) configurations of the $\mathrm{PuO}_{3}\left(\mathrm{NO}_{3}\right)_{2}{ }^{-}$complex (HS geometry) and $\left\langle S^{2}\right\rangle$ values for the HS and BS configurations, respectively.

\begin{tabular}{cc}
\hline Parameter & Value \\
\hline$E_{\mathrm{HS}}-E_{\mathrm{BS}}(\mathrm{meV})$ & 123 \\
$\left\langle S^{2}\right\rangle_{\mathrm{HS}}$ & 3.78 \\
$\left\langle\mathrm{~S}^{2}\right\rangle_{\mathrm{BS}}$ & 1.77 \\
\hline
\end{tabular}

\section{Conclusions}

ESI of a nominally plutonium(IV) nitrate solution resulted in species corresponding to the four readily accessible oxidation states of plutonium: $\mathrm{Pu}(\mathrm{III}), \mathrm{Pu}(\mathrm{IV}), \mathrm{Pu}(\mathrm{V})$ and $\mathrm{Pu}(\mathrm{VI})$. Although changes in oxidation state can occur during ESI, which is an electrochemical process, the coexistence of these four oxidation states is consistent with solution chemistry and the known low reduction potentials for $\mathrm{Pu}(\mathrm{VI}), \mathrm{Pu}(\mathrm{V})$ and $\mathrm{Pu}(\mathrm{IV})$. A dominant species in the ESI mass spectrum was $\mathrm{Pu}^{\mathrm{IV}}\left(\mathrm{NO}_{3}\right)_{5}{ }^{-}$, which is generally not considered a significant solution species. Recognizing that ESI mass spectra do not directly represent solution speciation, this result nonetheless suggests that $\mathrm{Pu}^{\mathrm{IV}}\left(\mathrm{NO}_{3}\right)_{5}{ }^{-}$should be considered when modeling plutonium nitrate solution speciation. CID-induced $\mathrm{NO}_{2}$ elimination from $\mathrm{Pu}^{\mathrm{III}}\left(\mathrm{NO}_{3}\right)_{4}{ }^{-}$and $\mathrm{Pu}^{\mathrm{IV}}\left(\mathrm{NO}_{3}\right)_{5}{ }^{-}$resulted in $\mathrm{Pu}^{\mathrm{V}} \mathrm{O}_{2}\left(\mathrm{NO}_{3}\right)_{2}{ }^{-}$and $\mathrm{Pu}^{\mathrm{VI}} \mathrm{O}_{2}\left(\mathrm{NO}_{3}\right)_{3}{ }^{-}$, respectively, demonstrating the direct synthesis of plutonyl from plutonium nitrate. CID of $\mathrm{Pu}^{\mathrm{VI}} \mathrm{O}_{2}\left(\mathrm{NO}_{3}\right)_{3}{ }^{-}$ resulted in loss of an additional $\mathrm{NO}_{2}$ molecule to produce $\mathrm{PuO}_{3}\left(\mathrm{NO}_{2}\right)_{2}{ }^{-}$; it was postulated that this species could have a $\mathrm{PuO}_{3}{ }^{+}$core in which the oxidation state is $\mathrm{Pu}(\mathrm{VII})$, and oxidation state known to exist in solution. However, DFT computations revealed that the structure of the $\mathrm{PuO}_{3}{ }^{+}$core in $\mathrm{PuO}_{3}\left(\mathrm{NO}_{2}\right)_{2}{ }^{-}$is similar to that of the $\mathrm{PuO}_{2}{ }^{2+}$ core in $\mathrm{PuO}_{2}\left(\mathrm{NO}_{3}\right)_{3}{ }^{-}$, with an oxidation state of $\mathrm{Pu}(\mathrm{VI})$ in both. The $\mathrm{PuO}_{3}\left(\mathrm{NO}_{2}\right)_{2}{ }^{-}$complex can be represented as $\mathrm{PuO}_{2}{ }^{2+}$ coordinated in the equatorial plane by two nitrate ligands and one radical oxygen atom. The results indicate that $\mathrm{Pu}(\mathrm{VI})$ is not readily oxidized to $\mathrm{Pu}(\mathrm{VII})$ in the gas phase, as might have been expected, but rather that a species comprising a radical oxygen atom bound to $\mathrm{Pu}(\mathrm{VI})$ is the more favorable bonding configuration.

\section{Supporting Information}

CID mass spectra of $\mathrm{Pu}\left(\mathrm{NO}_{3}\right)_{4}{ }^{-}$and $\mathrm{PuO}\left(\mathrm{NO}_{3}\right)_{3}{ }^{-}$. SR geometrical parameters of the bare $\mathrm{PuO}_{2}{ }^{+}, \mathrm{PuO}_{2}{ }^{2+}$, and $\mathrm{PuO}_{3}{ }^{+}$ions, $\mathrm{SO}$ geometrical parameters of the bare ions and of the complexes, SR molecular geometries of the $\mathrm{PuO}_{2}\left(\mathrm{NO}_{3}\right)_{2}{ }^{-}, \mathrm{PuO}_{2}\left(\mathrm{NO}_{3}\right)_{3}{ }^{-}$, and $\mathrm{PuO}_{3}\left(\mathrm{NO}_{3}\right)_{2}{ }^{-}$ plutonium nitrate complexes, SRMullikenatomic charges and atomic spin populations of the bare $\mathrm{PuO}_{2}{ }^{+}, \mathrm{PuO}_{2}{ }^{2+}$, and $\mathrm{PuO}_{3}{ }^{+}$ions, SO Mulliken atomic charges of the bare ions and of the 
complexes, and energy difference between the HS and BS configurations of the bare $\mathrm{PuO}_{3}{ }^{+}$ ion (HS geometry) and $\left\langle S^{2}\right\rangle$ values for the HS and BS configurations, respectively.

\section{Acknowledgement}

The work of YG, PXR and JKG wasfullysupported by the U.S. Department of Energy, Office of Basic Energy Sciences, Heavy ElementChemistry, at LBNL underContract No. DE-AC0205CH11231. 


\section{References}

(1) Clark, D. L.; Hecker, S. S.; Jarvinen, G. D.; Neu, M. P. In The Chemistry of the Actinide and Transactinide Elements; 3rd ed.; Morss, L. R., Edelstein, N. M., Fuger, J., Eds.; Springer: Dordrecht, The Netherlands, 2006; Vol. 2, p 813-1264.

(2) Dyall, K. G. High Oxidation States in Actinide Chemistry: A DHF Investigation of Some Trends Exemplified by the $\mathrm{AnO}_{2} \mathrm{~F}_{4}$ Species. Chem. Phys.2005, 311, 19-24.

(3) Krot, N. N.; Gel'man, A. D. Production of Neptunium and Plutonium in Heptavalent State. Dokl. Akad. Nauk SSSR1967, 177, 124.

(4) Spitsyn, V. I.; Gel'man, A. D.; Krot, N. N.; Mefodiye, M. P.; Zakharov, F. A.; Komkov, Y. A.; Shilov, V. P.; Smirnova, I. V. Heptavalent State of Neptunium and Plutonium. J Inorg Nucl Chem1969, 31, 2733-2745.

(5) Keller, C.; Seiffert, H. Heptavalent Plutonium. Angew Chem Int Edit1969, 8, 279-280.

(6) Tananaev, I. G.; Nikonov, M. V.; Myasoedov, B. F.; Clark, D. L. Plutonium in Higher Oxidation States in Alkaline Media. J Alloy Compd2007, 444, 668-672.

(7) Domanov, V. P.; Lobanov, Y. V. Refinement of Data on the Volatility of Octavalent Plutonium in the Form of Tetraoxide $\mathrm{PuO}_{4}$. Radiochemistry2009, 51, 14-17.

(8) Nikonov, M. V.; Kiselev, Y. M.; Tananaev, I. G.; Myasoedov, B. F. Plutonium Volatility in Ozonization of Alkaline Solutions of $\mathrm{Pu}(\mathrm{VI})$ Hydroxo Complexes. Dokl Chem2011, 437, 69-71.

(9) Huang, W.; Xu, W. H.; Su, J.; Schwarz, W. H. E.; Li, J. Oxidation States, Geometries, and Electronic Structures of Plutonium Tetroxide $\mathrm{PuO}_{4}$ Isomers: Is Octavalent Pu Viable? Inorg Chem2013, 52, 14237-14245. 
(10) Zaitsevskii, A. V.; Titov, A. V.; Mal'kov, S. S.; Tananaev, I. G.; Kiselev, Y. M. On the Existence of Oxide Molecules of Plutonium in Highest Oxidation States. Dokl Chem2013, 448, 1-3.

(11) Gabelnick, S. D.; Reedy, G. T.; Chasanov, M. G. Infrared-Spectra and Structure of Some Matrix-Isolated Lanthanide and Actinide Oxides. J Chem Phys1974, 60, 1167-1171.

(12) Li, F. M.; Byers, M. A.; Houk, R. S. Tandem Mass Spectrometry of Metal Nitrate Negative Ions Produced by Electrospray lonization. J Am Soc Mass Spectrom2003, 14, 671-679.

(13) Schröder, D.; de Jong, K. P.; Roithova, J. Gas-Phase Model Studies Relevant to the Decomposition of Transition-Metal Nitrates $\mathrm{M}\left(\mathrm{NO}_{3}\right)_{2}(\mathrm{M}=\mathrm{Co}$, $\mathrm{Ni}$ ) into Metal-Oxo Species. Eur J Inorg Chem2009, 2121-2128.

(14) Franski, R.; Sobieszczuk, K.; Gierczyk, B. Mass Spectrometric Decomposition of $\left[\mathrm{Mn}^{\mathrm{n}+}\left(\mathrm{NO}_{3}{ }^{-}\right)_{\mathrm{n}+1}\right]^{-}$Anions Originating from Metal Nitrates $\mathrm{M}\left(\mathrm{NO}_{3}\right)_{n}$. Int. J. Mass Spectrom. 2014, 369, 98-104.

(15) Rios, D.; Rutkowski, P. X.; Shuh, D. K.; Bray, T. H.; Gibson, J. K.; Van Stipdonk, M. J. Electron Transfer Dissociation of Dipositive Uranyl and Plutonyl Coordination Complexes. J Mass Spectrom2011, 46, 1247-1254.

(16) Gronert, S. Estimation of Effective Ion Temperatures in a Quadrupole Ion Trap. J Am Soc Mass Spectrom1998, 9, 845-848.

(17) Gong, Y.; Gibson, J. K. Formation and Characterization of the Uranyl-SO $\mathrm{S}_{2}$ Complex, $\mathrm{UO}_{2}\left(\mathrm{CH}_{3} \mathrm{SO}_{2}\right)\left(\mathrm{SO}_{2}\right)^{-}$. J. Phys. Chem. A2013, 117, 783-787.

(18) Rutkowski, P. X.; Michelini, M. C.; Bray, T. H.; Russo, N.; Marçalo, J.; Gibson, J. K. Hydration of Gas-Phase Ytterbium Ion Complexes Studied by Experiment and Theory. Theor Chem Acc2011, 129, 575-592.

(19) Rios, D.; Michelini, M. C.; Lucena, A. F.; Marcalo, J.; Bray, T. H.; Gibson, J. K. Gas-Phase Uranyl, Neptunyl, and Plutonyl: Hydration and Oxidation Studied by Experiment and Theory. Inorg Chem2012, 51, 6603-6614. 
(20) Frisch, M. J. et al. Gaussian 2009, Revision D.01, Gaussian, Inc., Wallingford CT, 2013.

(21) Kovacs, A.; Konings, R. J. M. Computed Vibrational Frequencies of Actinide Oxides $\mathrm{AnO}^{(0 /+/ 2+)}$ and $\mathrm{AnO}_{2}{ }^{(0 /+/ 2+)}(\mathrm{An}=\mathrm{Th}, \mathrm{Pa}, \mathrm{U}, \mathrm{Np}, \mathrm{Pu}, \mathrm{Am}, \mathrm{Cm}) . J$. Phys. Chem. A2011, 115, 6646-6656.

(22) Perdew, J. P.; Emzerhof, M.; Burke, K. Rationale for Mixing Exact Exchange with Density Functional Approximations. J Chem Phys1996, 105, 9982-9985.

(23) Adamo, C.; Barone, V. Toward Reliable Density Functional Methods Without Adjustable Parameters: The PBEO Model. J Chem Phys1999, 110, 6158-6170.

(24) Pereira, C. C. L.; Maurice, R.; Lucena, A. F.; Hu, S. X.; Gonçalves, A. P.; Marçalo, J.; Gibson, J. K.; Andrews, L.; Gagliardi, L. Thorium and Uranium Carbide Cluster Cations in the Gas Phase: Similarities and Differences between Thorium and Uranium. Inorg Chem2013, 52, 10968-10975.

(25) Cao, X. Y.; Dolg, M.; Stoll, H. Valence Basis Sets for Relativistic Energy-Consistent Small-Core Actinide Pseudopotentials. J Chem Phys2003, 118, 487-496.

(26) Cao, X. Y.; Dolg, M. Segmented Contraction Scheme for Small-Core Actinide Pseudopotential Basis Sets. J Mol Struc-Theochem2004, 673, 203-209.

(27) Weigend, F.; Ahlrichs, R. Balanced Basis Sets of Split Valence, Triple Zeta Valence and Quadruple Zeta Valence Quality for $\mathrm{H}$ to Rn: Design and Assessment of Accuracy. Phys Chem Chem Phys2005, 7, 3297-3305.

(28) Rappoport, D.; Furche, F. Property-Optimized Gaussian Basis Sets for Molecular Response Calculations. J Chem Phys2010, 133,

(29) Nichols, P.; Govind, N.; Bylaska, E. J.; de Jong, W. A. Gaussian Basis Set and Planewave Relativistic Spin-Orbit Methods in NWChem. $J$ Chem Theory Comput2009, 5, 491-499. 
(30) Valiev, M.; Bylaska, E. J.; Govind, N.; Kowalski, K.; Straatsma, T. P.; Van Dam, H. J. J.; Wang, D.; Nieplocha, J.; Apra, E.; Windus, T. L.; de Jong, W. NWChem: A Comprehensive and Scalable Open-Source Solution for Large Scale Molecular Simulations. Comput Phys Commun2010, 181, 1477-1489.

(31) Küchle, W.; Dolg, M.; Stoll, H.; Preuss, H. Energy-Adjusted Pseudopotentials for the Actinides - Parameter Sets and Test Calculations for Thorium and Thorium Monoxide. J Chem Phys1994, 100, 7535-7542.

(32) van Wüllen, C. Spin densities in two-component relativistic density functional calculations: Noncollinear versus collinear approach. J Comput Chem2002, 23, 779-785.

(33) Marenich, A. V.; Jerome, S. V.; Cramer, C. J.; Truhlar, D. G. Charge Model 5: An Extension of Hirshfeld Population Analysis for the Accurate Description of Molecular Interactions in Gaseous and Condensed Phases. $J$ Chem Theory Comput2012, 8, 527-541.

(34) Hirshfeld, F. L. Bonded-Atom Fragments for Describing Molecular Charge-Densities. Theor Chim Acta1977, 44, 129-138.

(35) Heisenberg, W. On the Theory of Ferromagnetism. Z Phys1928, 49, 619-636.

(36) Dirac, P. A. M. Quantum Mechanics of Many-Electron Systems. Proc. Royal Soc. London1929, 123, 714-733.

(37) Vanvleck, J. H. A Survey of the Theory of Ferromagnetism. Rev Mod Phys1945, 17, 27-47.

(38) Yamaguchi, K. Electronic-Structures of Biradicals in Unrestricted Hartree-Fock Approximation. Chem Phys Lett1975, 33, 330-335.

(39) Yamaguchi, K.; Fukui, H.; Fueno, T. Molecular-Orbital (MO) Theory for Magnetically Interacting Organic-Compounds - Abinitio MO Calculations of the Effective Exchange Integrals for Cyclophane-Type Carbene Dimers. Chem Lett1986, 625-628. 
(40) Rios, D.; Rutkowski, P. X.; Van Stipdonk, M. J.; Gibson, J. K. GasPhase Coordination Complexes of Dipositive Plutonyl, $\mathrm{PuO}_{2}{ }^{2+}:$ Chemical Diversity Across the Actinyl Series. Inorg Chem2011, 50, 4781-4790.

(41) McDonald, L. W.; Campbell, J. A.; Clark, S. B. Failure of ESI Spectra to Represent Metal-Complex Solution Composition: A Study of LanthanideCarboxylate Complexes. Anal Chem2014, 86, 1023-1029.

(42) Veirs, D. K.; Smith, C. A.; Berg, J. M.; Zwick, B. D.; Marsh, S. F.; Allen, P.; Conradson, S. D. Characterization of the Nitrate Complexes of Pu(IV) Using Absorption-Spectroscopy, N-15 NMR, and EXAFS. J Alloy Compd1994, 213, 328-332.

(43) Kubic, W. L.; Jackson, J. C. A Thermodynamic Model of Plutonium (IV) Nitrate Solutions. J Radioanal Nucl Ch2012, 293, 601-612.

(44) Lias, S. G.; Bartmess, J. E.; Liebman, J. F.; Holmes, J. L.; Levin, R. D.; Mallard, W. G. In NIST Chemistry WebBook, NIST Standard Reference Database Number 69; Linstrom, P. J., Mallard, W. G., Eds.; National Institue of Standards and Technology: Gaithersburg, MD, 2014.

(45) Lias, S. G.; Bartmess, J. E.; Liebman, J. F.; Holmes, J. L.; Levin, R. D.; Mallard, W. G. Gas-Phase Ion and Neutral Thermochemistry. J Phys Chem Ref Data1988, 17, 1-861.

(46) La Macchia, G.; Infante, I.; Raab, J.; Gibson, J. K.; Gagliardi, L. A theoretical study of the ground state and lowest excited states of PuOO/+/+2 and PuO20/+/+2. Phys Chem Chem Phys2008, 10, 7278-7283.

(47) Ismail, N.; Heully, J. L.; Saue, T.; Daudey, J. P.; Marsden, C. J. Theoretical Studies of the Actinides: Method Calibration for the $\mathrm{UO}_{2}{ }^{2+}$ and $\mathrm{PuO}_{2}{ }^{2+}$ Ions. Chem Phys Lett1999, 300, 296-302.

(48) Gendron, F.; Pritchard, B.; Bolvin, H.; Autschbach, J. Magnetic Resonance Properties of Actinyl Carbonate Complexes and Plutonyl(VI)-trisnitrate. Inorg Chem2014, 53, 8577-8592. 
(49) Odoh, S. O.; Schreckenbach, G. Theoretical Study of the Structural Properties of Plutonium(IV) and (VI) Complexes. J. Phys. Chem. A2011, 115, 14110-14119.

(50) Craw, J. S.; Vincent, M. A.; Hillier, I. H.; Wallwork, A. L. Ab-Initio Quantum-Chemical Calculations on Uranyl Uo22+ Plutonyl Puo22+, and Their Nitrates and Sulfates. J Phys Chem-Us1995, 99, 10181-10185.

(51) Hay, P. J.; Martin, R. L.; Schreckenbach, G. Theoretical studies of the properties and solution chemistry of $\mathrm{AnO}(2)(2+)$ and $\mathrm{AnO}(2)(+)$ aquo complexes for $A n=U, N p$, and Pu. J. Phys. Chem. A2000, 104, 6259-6270.

(52) Dzyaloshinsky, I. A Thermodynamic Theory of Weak Ferromagnetism of Antiferromagnetics. J Phys Chem Solids1958, 4, 241-255.

(53) Moriya, T. Anisotropic Superexchange Interaction and Weak Ferromagnetism. Phys Rev1960, 120, 91-98.

(54) Maurice, R.; de Graaf, C.; Guihery, N. Theoretical determination of spin Hamiltonians with isotropic and anisotropic magnetic interactions in transition metal and lanthanide complexes. Phys Chem Chem Phys2013, 15, 18784-18804. 


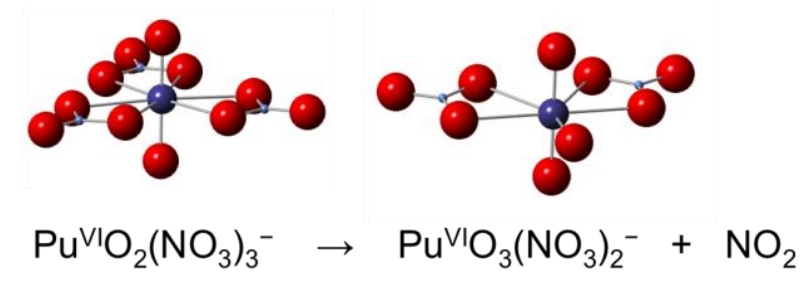

The plutonium oxidation states $\mathrm{Pu}(\mathrm{III}), \mathrm{Pu}(\mathrm{IV}), \mathrm{Pu}(\mathrm{V})$ and $\mathrm{Pu}(\mathrm{VI})$ wereidentified in gas-phase nitrate complexes. Fragmentation of the $\mathrm{Pu}^{\mathrm{VI}} \mathrm{O}_{2}\left(\mathrm{NO}_{3}\right)_{3}{ }^{-}$complexresulted in $\mathrm{NO}_{2}$ elimination to yield $\mathrm{PuO}_{3}\left(\mathrm{NO}_{3}\right)_{2}{ }^{-}$, the computed structure of which is a plutonyl(VI) core, $\mathrm{Pu}^{\mathrm{VI}} \mathrm{O}_{2}{ }^{2+}$, coordinated in the equatorial plane by two nitrate ligands and a radical oxygen atom. It is concluded that $\mathrm{Pu}(\mathrm{VI})$ is not oxidized to $\mathrm{Pu}(\mathrm{VII})$ by an oxygen radical, revealing the limited stability of oxidation states higher than $\mathrm{Pu}(\mathrm{VI})$. 